\title{
Cellular origin and development of secondary somatic embryos in Oncidium leaf cultures
}

\author{
J.-T. CHEN ${ }^{1 *}$ and P.-I. HONG ${ }^{2}$ \\ Institute of Biotechnology, National University of Kaohsiung, Kaohsiung 811, Taiwan, Republic of China ${ }^{1}$ \\ Institute of Plant and Microbial Biology, Academia Sinica, Taipei 115, Taiwan, Republic of China ${ }^{2}$
}

\begin{abstract}
We report here for the first time that fully differentiated stomatal guard cells have the ability to form directly secondary somatic embryos. Histological and scanning electron microscopy studies reveal that the stomata are formed on primary embryos of both Oncidium cultivars Gower Ramsey and Sweet Sugar. Secondary embryogenesis from these guard cells could be induced by several plant growth regulators (PGRs), including $\mathrm{N}^{6}$-benzyladenine, kinetin, thidiazuron, 1-aminocyclopropane-1carboxylic acid (ACC), ancymidol and 2,3,5-triiodobenzoic acid. When compared with other PGRs, ACC at concentration $1 \mathrm{mg} \mathrm{dm}^{-3}$ resulted in highest number of secondary embryos that were derived from guard cells. The present communication provides a model system for studying factors and mechanism affecting totipotency or embryogenetic capacity of guard cells.
\end{abstract}

Additional key words: direct somatic embryogenesis, growth regulators, guard cell, morphogenetic pathway, orchid.

\section{Introduction}

Somatic embryogenesis is defined as a process in which a bipolar structure, resembling a zygotic embryo, develops from a non-zygotic cell without vascular connection with the original tissue (Von Arnold et al. 2002). In general, somatic embryogenesis can be initiated by two pathways: directly on explanted tissues, and indirectly from callus (Williams and Maheswaran 1986). Somatic embryos are used for studying regulation of embryo development, but also as a tool for large scale vegetative propagation (Von Arnold et al. 2002). Secondary somatic embryogenesis is a phenomenon by which new embryos are initiated from other somatic embryos in culture (Ogata et al. 2005, Uzelac et al. 2007, Karami et al. 2008). In Oncidium orchids, regeneration systems via direct and indirect somatic embryogenesis have been established in our previous reports (Chen et al. 1999, Chen and Chang 2000). However, the cellular origin of secondary embryos has not been elucidated in this genus.

Over the last decade, the establishment of regeneration protocols from isolated guard cells is the basic technique required for the application of genetic approaches to stomatal physiology and related gene function (Müller-Röber et al. 1998). In several reports, the totipotency of guard cells has been proved, such as in tree tobacco (Sahgal et al. 1994, Taylor et al. 1998), sugar-beet (Hall et al. 1995, Wiśniewska and MajewskaSawka 2007) and cotton (Nobre et al. 2001). These previous protocols induce plant regeneration from guard cells mainly via indirect pathways and it may increase the complexity of physiological status of cytodifferentiation. In this present communication, we describe a novel protocol for the induction of secondary embryos directly from guard cells on embryogenic cultures from leaf explants of Oncidium.

Received 25 March 2010, accepted 18 November 2010.

Abbreviations: 2,4-D - 2,4-dichlorophenoxyacetic acid; ABA - abscisic acid, ACC - 1-aminocyclopropane-1-carboxylic acid, ancymidol - $\alpha$-cyclopropyl- $\alpha$-(4-methoxyphenyl)-5-pyrimidinemethanol, BA - $\mathrm{N}^{6}$-benzyladenine, $\mathrm{GA}_{3}$ - gibberellin $\mathrm{A}_{3}$, kin - kinetin ( $\mathrm{N}^{6}$-furfuryladenine), MS - Murashige and Skoog (1962) medium; TDZ - thidiazuron [1-phenyl-3-(1,2,3-thiadiazol-5-yl)-urea], TIBA - 2,3,5-triiodobenzoic acid.

Acknowledgement: Experiments were conducted at Institute of Biotechnology, National University of Kaohsiung and at Institute of Plant \& Microbial Biology, Academia Sinica, Taiwan, Republic of China.

* Author for correspondence; fax: (+886) 75919 404), e-mail: jentsung@nuk.edu.tw 


\section{Materials and methods}

In vitro grown plantlets derived from leaf somatic embryos of Oncidium cv. Gower Ramsey and cv. Sweet Sugar were maintained on hormone-free $1 / 2$ Murashige and Skoog (1962; MS) medium with a 2-month-interval of subculture as described by Chen et al. (1999). These plantlets were used as donor plants. Tips (about $1 \mathrm{~cm}$ long) taken from young leaves of donor plants were used as explants to induce direct somatic embryogenesis (Chen and Chang 2001). Plant growth regulators were sterilized by filtration using $0.2 \mu \mathrm{m}$ filters (Gelman Sciences, Ann Arbor, USA), and added to $1 / 2$ MS medium. Explants were placed adaxial-side-up on the surface of culture media and incubated in $80 \times 15 \mathrm{~mm}$ Petri dishes (Alpha Plus Scientific Corporation, Taoyuan, Taiwan) under a 16-h photoperiod with irradiance of $28-36 \mu \mathrm{mol} \mathrm{m}^{-2} \mathrm{~s}^{-1}$ (daylight fluorescent tubes $F L-30 D / 29,40 \mathrm{~W}$, China Electric Company, Taipei, Taiwan) and at temperature of $26 \pm 1^{\circ} \mathrm{C}$.

Two independent experiments were performed to evaluate the effects of $\mathrm{N}^{6}$-benzyladenine (BA), kinetin (kin) and thidiazuron (TDZ) at concentrations of $0.1,0.5$ and $1 \mathrm{mg} \mathrm{dm} \mathrm{m}^{-3}$ on direct embryo formation from leaf explants of cvs. Gower Ramsey and Sweet Sugar. The control treatment was placed on hormone-free basal medium. The frequency of embryo-forming explants and the mean number of embryos per explant were determined for each trial. Four explants were placed in each dish as one replicate. Four replicates were established for each treatment. The number of embryos formed from each responding explant was counted under a stereomicroscope (SZH, Olympus, Tokyo, Japan) at the protocorm stage. Numbers of directly formed embryos were scored after one month of culture using histological examination. Four embryo-bearing explants were analyzed for each treatment. The percentages of

\section{Results and discussion}

It has been reported that exogenous cytokinins could promote direct embryogenesis of Oncidium spp. (Chen et al. 1999, Chen and Chang 2001, Su et al. 2006). In this report, we used histology and scanning electron microscopy to evaluate the effects of three cytokinins (BA, kinetin and TDZ) on the cellular origins of embryos during primary and secondary embryogenesis in two cultivars of Oncidium, Gower Ramsey and Sweet Sugar. After 2 months of culture, the highest response was obtained at $1 \mathrm{mg} \mathrm{dm}^{-3} \mathrm{TDZ}$ with 87.5 and $75 \%$ of embryogenesis frequencies and 9.8 and 8.0 embryos per explant in Gower Ramsey and Sweet Sugar, respectively (Table 1). In our previous report, histological observation reveals that embryos could be induced from different cells of the leaf explant, including the epidermal cell embryogenesis from different cell types were counted under a light microscopy. The stomata formed on primary embryos were scored after two months of culture using scanning electron microscopy. Five embryo-bearing explants were analyzed for each treatment.

BA, kin and TDZ at different concentrations, 1-aminocyclopropane-1-carboxylic acid (ACC), $\mathrm{AgNO}_{3}$, gibberellic acid $\left(\mathrm{GA}_{3}\right)$, ancymidol, abscisic acid (ABA), 2,4-dichlorophenoxyacetic acid (2,4-D) and 2,3,5triiodobenzoic acid (TIBA) alone or combined with TDZ were used to test their effects on secondary embryogenesis from leaf-derived embryos. Results were scored under a stereomicroscope and scanning electron microscope.

Tissues for histological observations were fixed in FAA $(95 \%$ ethyl alcohol + glacial acetic acid + formaldehyde + water, 10:1:2:7), dehydrated in a tertiarybutyl-alcohol series, embedded in paraffin wax, sectioned at $10 \mu \mathrm{m}$ thickness and stained with $0.5 \%$ safranin- $\mathrm{O}$ and $0.1 \%$ fast green (Jensen 1962).

Samples for scanning electron microscopy were fixed in $2.5 \%$ glutaraldehyde in $0.1 \mathrm{M}$ phosphate buffer $\left(\mathrm{pH} 7.0\right.$ ) for $4 \mathrm{~h}$ at $4{ }^{\circ} \mathrm{C}$, dehydrated in ethanol (Dawns 1971), dried using a critical point dryer (HCP-2, Hitachi, Tokyo, Japan), and coated with gold in an ion coater (IB-2, Giko Engineering Company, Tokyo, Japan). A scanning electron microscope (DSM-950, Carl Zeiss, Jena, Germany) was used for examination and photography of the specimen.

Data expressed as percentage were transformed using arc sine prior to ANOVA and converted back to the original scale (Compton 1994). Treatment means were compared by following Duncan's multiple range test (Duncan 1955).

layer, the outer mesophyll cell layer, epidermal cells together with the outer mesophyll cells, and the inner mesophyll cells (Chen at al. 1999, Chen and Chang 2001). However, no embryos have been found from guard cells on the surfaces of leaf explants in both cultivars (Chen et al. 1999, Chen and Chang 2001). In this study, BA, kinetin and TDZ at $0.1,0.5$ and $1 \mathrm{mg} \mathrm{dm}^{-3}$ decreased embryogenesis frequencies from the epidermal cells in both cultivars. However, the embryogenesis frequencies of mesophyll cells and epidermal cells with mesophyll cells were enhanced by all of the PGR used in both cultivars (Table 2). The results show that exogenous cytokinins could significantly affect the embryogenic capacity and also alter the morphogenetic fate of leaf cells. It was suggested that PGR treatments could cause 
Table 1. Effects of BA, kinetin and TDZ on direct embryogenesis from leaf explants of Oncidium cvs. Gower Ramsey and Sweet Sugar. Data were scored after 2 months of culture. Four replicates (dishes) each with four leaf explants were performed for each treatment. Means with the same letters within columns are not significantly different at $P \leq 0.05$.

\begin{tabular}{|c|c|c|c|c|c|}
\hline \multirow{2}{*}{\multicolumn{2}{|c|}{$\begin{array}{l}\text { Treatments } \\
{\left[\mathrm{mg} \mathrm{dm}^{-3}\right]}\end{array}$}} & \multicolumn{2}{|c|}{$\begin{array}{l}\text { Embryogenesis } \\
{[\%]}\end{array}$} & \multicolumn{2}{|c|}{$\begin{array}{l}\text { Number of embryos } \\
\text { [explant }^{-1} \text { ] }\end{array}$} \\
\hline & & Ramsey & Sugar & Ramsey & Sugar \\
\hline Control & 0 & $43.8 \mathrm{c}$ & $31.3 \mathrm{~d}$ & $1.8 \mathrm{~d}$ & $1.1 \mathrm{f}$ \\
\hline \multirow[t]{3}{*}{ BA } & 0.1 & $56.3 \mathrm{bc}$ & $50.0 \mathrm{c}$ & $3.1 \mathrm{~d}$ & $2.7 \mathrm{~d}$ \\
\hline & 0.5 & $68.8 \mathrm{ab}$ & $56.3 \mathrm{bc}$ & $4.7 \mathrm{c}$ & $4.1 \mathrm{c}$ \\
\hline & 1.0 & $75.0 \mathrm{ab}$ & $56.3 \mathrm{bc}$ & $6.9 \mathrm{~b}$ & $5.1 \mathrm{c}$ \\
\hline \multirow[t]{3}{*}{ Kin } & 0.1 & $37.5 \mathrm{c}$ & $31.3 \mathrm{~d}$ & $1.6 \mathrm{~d}$ & $1.4 \mathrm{ef}$ \\
\hline & 0.5 & $37.5 \mathrm{c}$ & $31.3 \mathrm{~d}$ & $2.0 \mathrm{~d}$ & $1.8 \mathrm{def}$ \\
\hline & 1.0 & $43.8 \mathrm{c}$ & $31.3 \mathrm{~d}$ & $2.4 \mathrm{~d}$ & $2.3 \mathrm{de}$ \\
\hline \multirow[t]{3}{*}{ TDZ } & 0.1 & $68.8 \mathrm{ab}$ & $62.5 \mathrm{abc}$ & $5.9 \mathrm{bc}$ & $5.0 \mathrm{c}$ \\
\hline & 0.5 & $81.3 \mathrm{a}$ & $68.8 \mathrm{ab}$ & $8.6 \mathrm{a}$ & $7.6 \mathrm{~b}$ \\
\hline & 1.0 & $87.5 \mathrm{a}$ & $75.0 \mathrm{a}$ & $9.8 \mathrm{a}$ & $8.0 \mathrm{a}$ \\
\hline
\end{tabular}

more mesophyll cells to undergo dedifferentiation and become embryogenic (Table 1).

Although leaf guard cells could not formed embryos, scanning electron microscopy reveals that leaf-derived embryos contained stomata on their surfaces (Table 3). In the control treatment, the percentage of stomata-bearing primary embryos was 12.4 and $0 \%$ in Gower Ramsey and Sweet Sugar, respectively (Table 3). It was found that several cytokinins enhanced the numbers and the percentages of stomata-bearing primary embryos in both cultivars (Table 3 ). Together with the results of Table 2 , it was suggested that the increase of embryogenic mesophyll cells could also ensure a higher amount of stomata-bearing embryos.

Base on histology, embryos that originated from the epidermal cell layer (Fig. 1a) were not capable to bear leaf stomata on their surfaces. In contrast, embryos derived from mesophyll cells covered by a layer of epidermal cells may contain stomata (Chen et al. 1999). In addition, some mesophyll-derived embryos arose from

Table 2. Effects of BA, kinetin and TDZ on percentage of direct embryogenesis from different leaf cells of Oncidium cvs. Gower Ramsey and Sweet Sugar. Data were scored after 1 months of culture. Four replicates (dishes) each with four leaf explants were performed for each treatment. Means with the same letters within columns are not significantly different at $P \leq 0.05$.

\begin{tabular}{|c|c|c|c|c|c|c|c|}
\hline \multirow{2}{*}{\multicolumn{2}{|c|}{ Treatments $\left[\mathrm{mg} \mathrm{dm}^{-3}\right]$}} & \multicolumn{2}{|c|}{ Epidermal cells } & \multicolumn{2}{|c|}{ Mesophyll cells } & \multicolumn{2}{|c|}{ Epidermal + mesophyll cells } \\
\hline & & Ramsey & Sugar & Ramsey & Sugar & Ramsey & Sugar \\
\hline Control & 0 & $85 \mathrm{a}$ & $50 \mathrm{a}$ & $0 \mathrm{~b}$ & $5 \mathrm{c}$ & $15 \mathrm{c}$ & $45 \mathrm{~cd}$ \\
\hline \multirow[t]{3}{*}{$\mathrm{BA}$} & 0.1 & $70 \mathrm{ab}$ & $40 \mathrm{a}$ & $15 \mathrm{a}$ & $20 \mathrm{~b}$ & $15 \mathrm{c}$ & $40 \mathrm{~d}$ \\
\hline & 0.5 & $30 \mathrm{c}$ & $25 \mathrm{~b}$ & $25 \mathrm{a}$ & $30 a b$ & $45 \mathrm{~b}$ & $45 \mathrm{~cd}$ \\
\hline & 1.0 & $15 \mathrm{~cd}$ & $5 \mathrm{c}$ & $30 \mathrm{a}$ & $40 \mathrm{a}$ & $55 \mathrm{ab}$ & 55 abcd \\
\hline \multirow[t]{3}{*}{ Kin } & 0.1 & $55 \mathrm{~b}$ & $25 \mathrm{~b}$ & $20 \mathrm{a}$ & $25 \mathrm{ab}$ & $25 \mathrm{c}$ & $50 \mathrm{bcd}$ \\
\hline & 0.5 & $10 \mathrm{~d}$ & $5 \mathrm{c}$ & $25 \mathrm{a}$ & $35 \mathrm{ab}$ & $65 \mathrm{ab}$ & $60 \mathrm{abc}$ \\
\hline & 1.0 & $5 \mathrm{~d}$ & $0 \mathrm{c}$ & $30 \mathrm{a}$ & $35 \mathrm{ab}$ & $65 \mathrm{ab}$ & $65 \mathrm{ab}$ \\
\hline \multirow[t]{3}{*}{ TDZ } & 0.1 & $10 \mathrm{~d}$ & $5 \mathrm{c}$ & $20 \mathrm{a}$ & $25 \mathrm{ab}$ & $70 \mathrm{a}$ & $70 a$ \\
\hline & 0.5 & $5 \mathrm{~d}$ & $5 \mathrm{c}$ & $30 \mathrm{a}$ & $40 \mathrm{a}$ & $65 \mathrm{ab}$ & $50 \mathrm{bcd}$ \\
\hline & 1.0 & $5 \mathrm{~d}$ & $5 \mathrm{c}$ & $30 \mathrm{a}$ & $40 \mathrm{a}$ & $65 \mathrm{ab}$ & $55 \mathrm{abcd}$ \\
\hline
\end{tabular}

Table 3. Effects of BA, kinetin and TDZ on formation of stomata-bearing primary embryos from leaf explants of Oncidium cvs. Gower Ramsey and Sweet Sugar. Data were scored after 2 months of culture. Four replicates (dishes) each with four leaf explants were performed for each treatment. Means with the same letters within columns are not significantly different at $P \leq 0.05$.

\begin{tabular}{|c|c|c|c|c|c|c|c|}
\hline \multirow{2}{*}{\multicolumn{2}{|c|}{ Treatments $\left[\mathrm{mg} \mathrm{dm}^{-3}\right]$}} & \multicolumn{2}{|c|}{$\begin{array}{l}\text { Number of primary embryos } \\
\text { [explant }^{-1} \text { ] }\end{array}$} & \multicolumn{2}{|c|}{$\begin{array}{l}\text { Number of stomata-bearing primary } \\
\left.\text { embryos [explant }{ }^{-1}\right]\end{array}$} & \multicolumn{2}{|c|}{$\begin{array}{l}\text { Formation of stomata-bearing } \\
\text { primary embryos }[\%]\end{array}$} \\
\hline & & Ramsey & Sugar & Ramsey & Sugar & Ramsey & Sugar \\
\hline Control & 0 & $4.8 \mathrm{e}$ & $3.4 \mathrm{f}$ & $0.6 \mathrm{~d}$ & $0 \mathrm{f}$ & $12.4 \mathrm{abc}$ & $0 \mathrm{~d}$ \\
\hline \multirow[t]{3}{*}{ BA } & 0.1 & $5.6 \mathrm{e}$ & $5.0 \mathrm{de}$ & $0.4 \mathrm{~d}$ & 0.4 ef & $7.4 \mathrm{c}$ & $10.0 \mathrm{~cd}$ \\
\hline & 0.5 & $7.2 \mathrm{~d}$ & $7.8 \mathrm{c}$ & $1.0 \mathrm{~cd}$ & $1.0 \mathrm{de}$ & $15.0 \mathrm{abc}$ & $12.8 \mathrm{c}$ \\
\hline & 1.0 & $8.6 \mathrm{c}$ & $9.6 \mathrm{~b}$ & $1.8 \mathrm{bc}$ & $1.8 \mathrm{~cd}$ & $20.8 \mathrm{abc}$ & $18.8 \mathrm{bc}$ \\
\hline \multirow[t]{3}{*}{ Kin } & 0.1 & $4.6 \mathrm{e}$ & $4.2 \mathrm{ef}$ & $0.4 \mathrm{~d}$ & $0 \mathrm{f}$ & $9.0 \mathrm{bc}$ & $0 \mathrm{~d}$ \\
\hline & 0.5 & $4.8 \mathrm{e}$ & $6.0 \mathrm{~d}$ & $0.8 \mathrm{~cd}$ & 0.6 ef & $14.6 \mathrm{abc}$ & $9.0 \mathrm{~cd}$ \\
\hline & 1.0 & $5.2 \mathrm{e}$ & $9.4 \mathrm{~b}$ & $1.2 \mathrm{~cd}$ & $1.2 \mathrm{de}$ & $22.2 \mathrm{abc}$ & $13.0 \mathrm{c}$ \\
\hline \multirow[t]{3}{*}{ TDZ } & 0.1 & $10.4 \mathrm{~b}$ & $8.6 \mathrm{bc}$ & $2.4 \mathrm{ab}$ & $2.4 \mathrm{bc}$ & $23.5 \mathrm{abc}$ & $28.0 \mathrm{ab}$ \\
\hline & 0.5 & $12.2 \mathrm{a}$ & $11.2 \mathrm{a}$ & $3.2 \mathrm{a}$ & $3.2 \mathrm{~b}$ & $26.2 \mathrm{a}$ & $28.4 \mathrm{ab}$ \\
\hline & 1.0 & $13.2 \mathrm{a}$ & $12.2 \mathrm{a}$ & $3.4 \mathrm{a}$ & $4.2 \mathrm{a}$ & $25.8 \mathrm{ab}$ & $34.8 \mathrm{a}$ \\
\hline
\end{tabular}



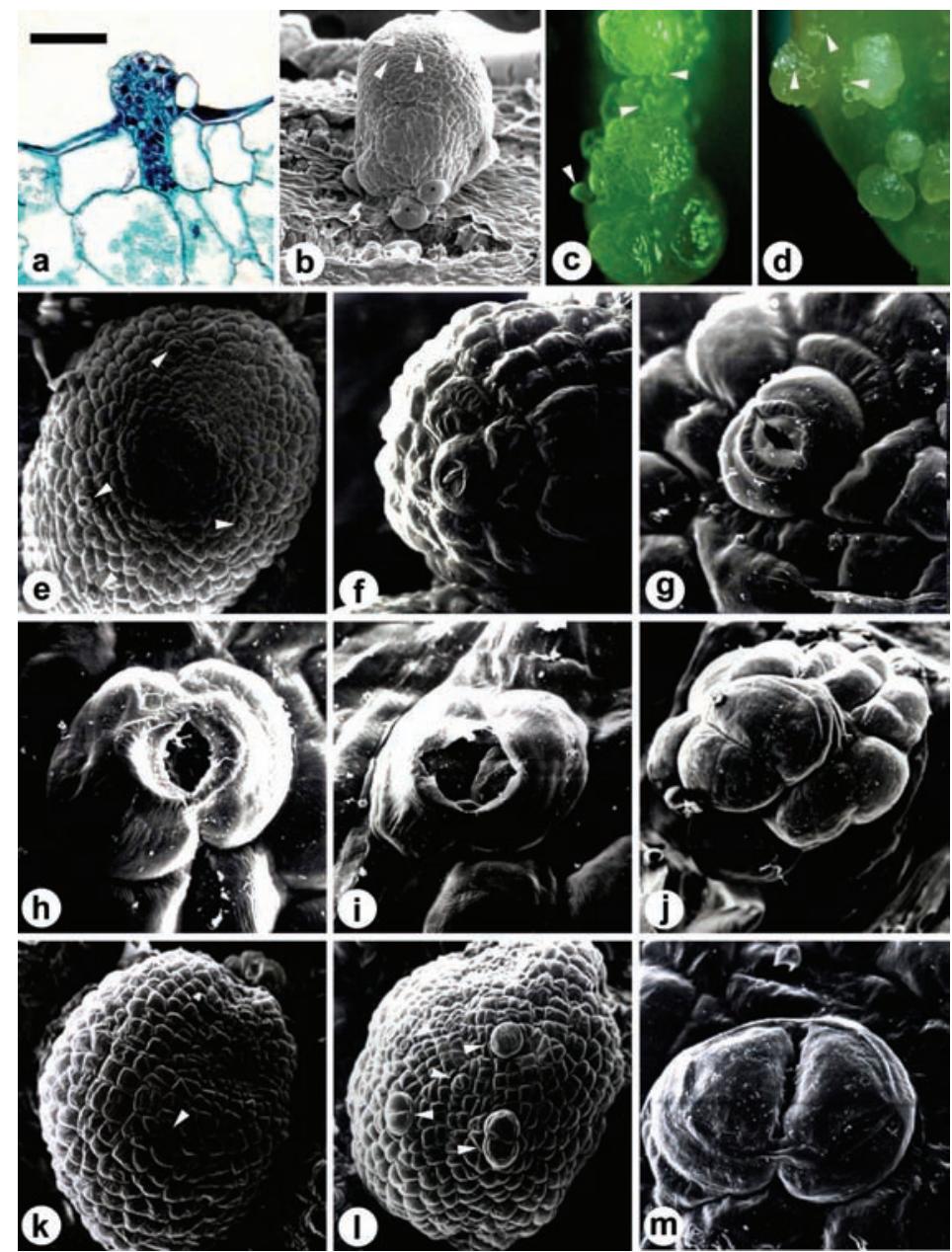

Fig. 1. Somatic embryogenesis and secondary embryogenesis from leaf explants of Oncidium (bar in upper left panel is fitting for all panels). $a$ - the embryo originated from an epidermal cell and consists of smaller embryonic cells with large and densely stained nucleus $($ bar $=30 \mu \mathrm{m}) . b$ - a globular embryo with several stomata (arrowhead) on the anterior surface and secondary embryos (asterisk) formed on the posterior region (bar $=15 \mu \mathrm{m}) . c$ - secondary embryos (arrowhead) arose from primary leaf-derived embryos on a leaf explant of cv. Gower Ramsey $($ bar $=0.45 \mathrm{~mm}) . d$ - secondary embryos (arrowhead) of cv. Sweet Sugar $($ bar $=1 \mathrm{~mm}) . e$ - a leaf-derived embryo developed stomata (arrowhead) on the surface $($ bar $=250 \mu \mathrm{m}) . f$ - a stoma became swelling $(b a r=20 \mu \mathrm{m}) . g, h$ - differentiated guard cells of stomata enlarged gradually (bar $=20$ and $30 \mu \mathrm{m}$, respectively). $i$ - enlarged guard cells broke the cuticle layer $($ bar $=50 \mu \mathrm{m}) . j$ - a secondary embryo formed directly from guard cells which consists of two extraordinary large cells at the anterior side $($ bar $=50 \mu \mathrm{m}) . k$ - a leaf-derived embryo developed stomata (arrowhead) on the surface $($ bar $=170 \mu \mathrm{m}) . \quad l$ - several stomata (arrowhead) became swelling on the surface of a primary embryo $($ bar $=100 \mu \mathrm{m})$. $m$ - a secondary proembryo formed from guard cells directly $($ bar $=20 \mu \mathrm{m})$.

cleavage of the leaf epidermis, and it was not possible to receive stomata from their parent explants (Chen et al. 1999). The present investigation showed that stomata could be found on the anterior surface of the primary embryo and in the mean time several secondary embryos were formed on the posterior region (Fig. 1b)

The secondary embryo formation varied in different plants. In Quercus suber, secondary embryos originated form the root pole of primary embryos (Puigderrajols et al. 1996). Ćalić et al. (2005) showed that secondary embryos of Aesculus hippocastanum appeared on the cotyledons and radiculi of embryos derived from suspension and anther cultures. In carrot, secondary embryos formed in the hypocotyl and root regions of primary embryos after they have developed into the torpedo stage (Ogata et al. 2005). Dos Santos et al. (1983) reported that secondary embryos of alfalfa originated from single epidermal cells of primary embryos. Recently, histological analysis of the torpedo shape somatic embryo of alfalfa has revealed that secondary somatic embryos arose directly from single epidermal cells of hypocotyl axis after an unequal periclinal division (Uzelac et al. 2007).

In orchids, different origins of secondary embryos have been found in previous reports (Chen and Chang 2004, Chung et al. 2005, 2007, Kuo et al. 2005). In Phalaenopsis amabilis, secondary embryos formed at posterior regions of primary embryos, and originated 
Table 4. Effects of BA, kinetin and TDZ on the percentage of secondary embryogenesis and numbers of guard-cell-derived secondary embryos per explant from leaf explants of Oncidium cvs. Gower Ramsey and Sweet Sugar. Data were scored after 3 months of culture. Four replicates (dishes) each with four leaf explants were performed for each treatment. Means with the same letters within columns are not significantly different at $P \leq 0.05$.

\begin{tabular}{|c|c|c|c|c|c|}
\hline \multirow{2}{*}{\multicolumn{2}{|c|}{$\begin{array}{l}\text { Treatments } \\
{\left[\mathrm{mg} \mathrm{dm}^{-3}\right]}\end{array}$}} & \multicolumn{2}{|c|}{$\begin{array}{l}\text { Secondary } \\
\text { embryogenesis [\%] }\end{array}$} & \multicolumn{2}{|c|}{$\begin{array}{l}\text { Number of secondary } \\
\text { embryos [explant }^{-1} \text { ] }\end{array}$} \\
\hline & & Ramsey & Sugar & Ramsey & Sugar \\
\hline Control & 0 & $6.3 \mathrm{~d}$ & $6.3 \mathrm{c}$ & $0 \mathrm{c}$ & $0 \mathrm{~d}$ \\
\hline \multirow[t]{3}{*}{$\mathrm{BA}$} & 0.1 & $12.5 \mathrm{~cd}$ & $12.5 \mathrm{c}$ & $0 \mathrm{c}$ & $0 \mathrm{~d}$ \\
\hline & 0.5 & $12.5 \mathrm{~cd}$ & $12.5 \mathrm{c}$ & $0.2 \mathrm{bc}$ & $0.6 \mathrm{~cd}$ \\
\hline & 1.0 & $18.75 \mathrm{~cd}$ & $18.8 \mathrm{bc}$ & $0.8 \mathrm{~b}$ & $1.0 \mathrm{c}$ \\
\hline \multirow[t]{3}{*}{ Kin } & 0.1 & $6.3 \mathrm{~d}$ & $0 \mathrm{c}$ & $0 \mathrm{c}$ & $0 \mathrm{~d}$ \\
\hline & 0.5 & $18.8 \mathrm{~cd}$ & $18.8 \mathrm{bc}$ & $0 \mathrm{c}$ & $0 \mathrm{~d}$ \\
\hline & 1.0 & $18.8 \mathrm{~cd}$ & $18.8 \mathrm{bc}$ & $0 \mathrm{c}$ & $0 \mathrm{~d}$ \\
\hline \multirow[t]{3}{*}{ TDZ } & 0.1 & $31.3 \mathrm{bc}$ & $37.5 \mathrm{ab}$ & $0.8 \mathrm{~b}$ & $1.4 \mathrm{bc}$ \\
\hline & 0.5 & $43.8 \mathrm{ab}$ & $37.5 \mathrm{ab}$ & $2.4 \mathrm{a}$ & $2.0 \mathrm{ab}$ \\
\hline & 1.0 & $50.0 \mathrm{a}$ & $56.3 \mathrm{a}$ & $2.8 \mathrm{a}$ & $2.8 \mathrm{a}$ \\
\hline
\end{tabular}

Table 5. Effects $1 \mathrm{mg} \mathrm{dm}{ }^{-3} \mathrm{TDZ}, \mathrm{ACC}, \mathrm{AgNO}_{3}, \mathrm{GA}_{3}$, ancymidol, ABA, 2,4-D, TIBA and their combinations on percentage of secondary embryogenesis and numbers of guard-cell-derived secondary embryos from leaf explants of Oncidium cvs. Gower Ramsey and Sweet Sugar. Data were scored after 3 months of culture. Four replicates (dishes) each with four leaf explants were performed for each treatment. Means with the same letters within columns are not significantly different at $P \leq 0.05$

\begin{tabular}{|c|c|c|c|c|}
\hline \multirow[t]{2}{*}{ Treatments } & \multicolumn{2}{|c|}{$\begin{array}{l}\text { Secondary } \\
\text { embryogenesis [\%] }\end{array}$} & \multicolumn{2}{|c|}{$\begin{array}{l}\text { Number. of secondary } \\
\left.\text { embryos [explant }^{-1}\right]\end{array}$} \\
\hline & Ramsey & Sugar & Ramsey & Sugar \\
\hline PGR-free & $6.3 \mathrm{c}$ & $6.3 \mathrm{~cd}$ & $0 \mathrm{~d}$ & $0 \mathrm{~d}$ \\
\hline TDZ & $50.0 \mathrm{~b}$ & $56.3 \mathrm{ab}$ & $2.8 \mathrm{~b}$ & $3.0 \mathrm{~b}$ \\
\hline ACC & $62.5 \mathrm{ab}$ & $62.5 \mathrm{a}$ & $4.8 \mathrm{a}$ & $4.3 \mathrm{a}$ \\
\hline $\mathrm{AgNO}_{3}$ & $0 \mathrm{c}$ & $0 \mathrm{~d}$ & $0 \mathrm{~d}$ & $0 \mathrm{~d}$ \\
\hline $\mathrm{GA}_{3}$ & $0 \mathrm{c}$ & $0 \mathrm{~d}$ & $0 \mathrm{~d}$ & $0 \mathrm{~d}$ \\
\hline ancymidol & $50.0 \mathrm{~b}$ & $43.8 \mathrm{~b}$ & $2.8 \mathrm{~b}$ & $3.3 \mathrm{~b}$ \\
\hline ABA & $6.3 \mathrm{c}$ & $0 \mathrm{~d}$ & $0 \mathrm{~d}$ & $0 \mathrm{~d}$ \\
\hline $2,4-\mathrm{D}$ & $0 \mathrm{c}$ & $0 \mathrm{~d}$ & $0 \mathrm{~d}$ & $0 \mathrm{~d}$ \\
\hline TIBA & $12.5 \mathrm{c}$ & $12.5 \mathrm{~cd}$ & $1.5 \mathrm{c}$ & $1.0 \mathrm{c}$ \\
\hline $\mathrm{TDZ}+\mathrm{ACC}$ & $68.8 \mathrm{a}$ & $62.5 \mathrm{a}$ & $5.0 \mathrm{a}$ & $4.3 \mathrm{a}$ \\
\hline $\mathrm{TDZ}+\mathrm{AgNO}_{3}$ & $0 \mathrm{c}$ & $0 \mathrm{~d}$ & $0 \mathrm{~d}$ & $0 \mathrm{~d}$ \\
\hline $\mathrm{TDZ}+\mathrm{GA}_{3}$ & $12.5 \mathrm{c}$ & $12.5 \mathrm{~cd}$ & $0.5 \mathrm{~d}$ & $0.8 \mathrm{c}$ \\
\hline TDZ + ancymidol & $56.3 \mathrm{ab}$ & $56.3 \mathrm{ab}$ & $3.3 \mathrm{~b}$ & $3.3 \mathrm{~b}$ \\
\hline $\mathrm{TDZ}+\mathrm{ABA}$ & $0 \mathrm{c}$ & $0 \mathrm{~d}$ & $0 \mathrm{~d}$ & $0 \mathrm{~d}$ \\
\hline $\mathrm{TDZ}+2,4-\mathrm{D}$ & $0 \mathrm{c}$ & $0 \mathrm{~d}$ & $0 \mathrm{~d}$ & $0 \mathrm{~d}$ \\
\hline TDZ + TIBA & $12.5 \mathrm{c}$ & $18.8 \mathrm{c}$ & $0.8 \mathrm{~d}$ & $0.5 \mathrm{~cd}$ \\
\hline
\end{tabular}

from outer cell layers (Chen and Chang 2004, Kuo et al. 2005). However, in Dendrobium, it was reported that secondary embryogenesis occurred on adaxial sides of sheath leaves of primary embryos during subculture (Chung et al. 2005). In addition, secondary embryos of
Dendrobium were also found on anterior and posterior regions of primary embryos (Chung et al. 2007). In this study, it was found that the leaf-derived embryos of both cultivars could form secondary embryos during subculture on the same medium (Fig. 1c,d). In hormone-free medium, $6.3 \%$ of explants could form secondary embryos in both cultivars after 3 months of culture (Table 4). It was found that TDZ at concentrations of 0.1, 0.5 and $1 \mathrm{mg} \mathrm{dm}^{-3}$ significantly enhanced the percentages of secondary embryogenesis (Table 4). Furthermore, other growth regulators, including $\mathrm{ACC}, \mathrm{AgNO}_{3}, \mathrm{GA}_{3}$, ancymidol, ABA, 2,4-D and TIBA were used alone or combined with TDZ to test their effects on secondary embryo induction (Table 5). In a previous report, ACC was found to be effective in embryo production from leaf explants of Oncidium cv. Gower Ramsey (Chen and Chang 2004). In this study, $1 \mathrm{mg} \mathrm{dm}^{-3}$ ACC alone or combined with $1 \mathrm{mg} \mathrm{dm}^{-3} \mathrm{TDZ}$ induced higher percentages of secondary embryogenesis than $1 \mathrm{mg} \mathrm{dm}^{-3}$ TDZ in both cultivars (Table 5). It was also found that $\mathrm{AgNO}_{3}, \mathrm{GA}_{3}$ and 2,4-D were inhibitory in direct embryo induction, and significantly retarded secondary embryogenesis (Table 5). In contrast, ancymidol was found to be effective on direct embryo induction in previous report (Chen and Chang 2003b), and also resulted in enhancement of secondary embryogenesis in this study (Table 5). In a previous report, TIBA combined with TDZ could enhance direct embryo formation (Chen and Chang 2004). However, TIBA shows no significant effect on secondary embryogenesis in this study (Table 5).

BA at 0.5 and $1 \mathrm{mg} \mathrm{dm}^{-3}$ and TDZ at $0.1,0.5$ and $1 \mathrm{mg} \mathrm{dm}^{-3}$ could induce secondary embryos from guard cells in both cultivars (Table 4). However, kinetin gave no embryogenic response from guard cells (Table 4). TDZ at $1 \mathrm{mg} \mathrm{dm}{ }^{-3}$ resulted in highest number of embryos from guard cells with 2.8 secondary embryos per explant (Table 4). In a further test, $1 \mathrm{mg} \mathrm{dm}$-3 ACC alone or combined with $1 \mathrm{mg} \mathrm{dm}^{-3} \mathrm{TDZ}$ both resulted in a significantly higher number of secondary embryos than the treatment of $1 \mathrm{mg} \mathrm{dm}^{-3} \mathrm{TDZ}$ (Table 5). In cv. Gower Ramsey, scanning electron microscopy reveals that some stomata formed from the surface of the primary embryo (Fig. 1e). Initially, the stomata became swelling and enlarged (Fig. 1f). The swelling guard cells gradually developed and the cuticle layer was broken (Fig. 1g,h,i). Subsequently, the globular proembryo formed and it consisted of two extraordinary large cells at the anterior side of the embryo (Fig. 1j). In cv. Sweet Sugar, secondary embryogenesis was found on leaf-derived stomata-bearing embryos following a similar morphogenetic pathway as in cv. Gower Ramsey (Fig. $1 k, l, m$ ).

Stomatal guard cells have been induced to obtain regenerated plantlets in several plant species (Sahgal et al. 1994, Hall et al. 1995, Taylor et al. 1998, Nobre et al. 2001, Wiśniewska and Majewska-Sawka 2007). However, these previous protocols used isolated 
epidermal strips that contained guard cells or guard cell protoplasts to induce regeneration mainly via indirect somatic embryogenesis. In this report, we proved the

\section{References}

Ćalić, D., Zdravković-Korać, S., Radojević, Lj.: Secondary embryogenesis in androgenic embryo cultures of Aesculus hippocastanum L. - Biol. Plant. 49: 435-438, 2005.

Chen, J.T., Chang, C., Chang, W.C.: Direct somatic embryogenesis from leaf explants of Oncidium 'Gower Ramsey' and subsequent plant regeneration. - Plant Cell Rep. 19: 143-149, 1999.

Chen, J.T., Chang, W.C.: Efficient plant regeneration through somatic embryogenesis from callus cultures of Oncidium (Orchidaceae). - Plant Sci. 160: 87-93, 2000.

Chen, J.T., Chang, W.C.: Effects of auxins and cytokinins on direct somatic embryogenesis from leaf explants of Oncidium 'Gower Ramsey'. - Plant Growth Regul. 34: 229232, 2001.

Chen, J.T., Chang, W.C.: 1-aminocyclopropane-1-carboxylic acid enhances direct somatic embryogenesis from Oncidium leaf cultures. - Biol. Plant. 46: 455-458, 2003a.

Chen, J.T., Chang, W.C.: Effects of $\mathrm{GA}_{3}$, ancymidol, cycocel and paclobutrazol on direct somatic embryogenesis of Oncidium in vitro. - Plant Cell Tissue Organ Cult. 72: 105108,2003 b.

Chen, J.T., Chang, W.C.: TIBA affects the induction of direct somatic embryogenesis from leaf explants of Oncidium. Plant Cell Tissue Organ Cult. 79: 315-320, 2004.

Chung, H.H., Chen, J.T., Chang, W.C.: Cytokinins induce direct somatic embryogenesis of Dendrobium Chiengmai Pink and subsequent plant regeneration. - In Vitro Plant 41: 765-769, 2005.

Chung, H.H., Chen, J.T., Chang, W.C.: Plant regeneration through direct somatic embryogenesis from leaf explants of Dendrobium. - Biol. Plant. 51: 346-350, 2007.

Compton, M.E.: Statistical methods suitable for the analysis of plant tissue culture data. - Plant Cell Tissue Organ Cult. 37: 217-242, 1994.

Dawns, C.J.: Biological Techniques in Electron Microscopy. Barnes and Noble, New York 1971.

Dos Santos, A.V.P., Cutter, E.G., Davey, M.R.: Origin and development of somatic embryos in Medicago sativa L. (alfalfa). - Protoplasma 117: 107-115, 1983.

Duncan, D.B.: Multiple range and multiple $F$ test. - Biometrics 11: $1-42,1955$.

Hall, R.D., Verhoeven, H.A., Krens, F.A.: Computer-assisted identification of protoplasts responsible for rare division events reveals guard cell totipotency. - Plant Physiol. 107: 1379-1386, 1995.

Jensen, W.A.: Botanical Histochemistry. - Freeman, San Francisco 1962.

Kim, Y.W., Park, S.Y., Park, I.S., Moon, H.K.: Somatic embryogenesis and plant regeneration from immature seeds origin of secondary embryogenesis in Oncidum leaf cultures.

of Magnolia obovata Thunberg. - Plant Biotechnol. Rep. 1: 237-242, 2007.

Kuo, H.L., Chen, J.T., Chang, W.C.: Efficient plant regeneration through direct somatic embryogenesis from leaf explants of Phalaenopsis 'Little Steve'. - In Vitro Plant 41: 453-456, 2005.

Murashige, T., Skoog, F.: A revised medium for rapid growth and bioassays with tobacco tissue cultures. - Physiol. Plant. 15: 495-497, 1962.

Ogata, Y., Iizuka, M., Nakayama, D., Ikeda, M., Kamada, H., Koshiba, T.: Possible involvement of abscisic acid in the induction of secondary somatic embryogenesis on seedcoat-derived carrot somatic embryos. - Planta 221: 417-423, 2005.

Karami, O., Deljou, A., Kordestani, G.K.: Secondary somatic embryogenesis of carnation (Dianthus caryophyllus L.). Plant Cell Tissue Organ Cult. 92: 273-280, 2008.

Müller-Röber, B., Ehrhardt, T., Plesch, G.: Molecular features of stomatal guard cells. - J. exp. Bot. 49: 293-304, 1998.

Nobre, J., Keith, D.J., Dunwell, J.M: Morphogenesis and regeneration from stomatal guard cell complexes of cotton (Gossypium hirsutum L.). - Plant Cell Rep. 20: 8-15, 2001.

Puigderrajols, P., Fernández-Guijarro, B., Toribio, M., Molinas, M.: Origin and early development of secondary embryos in Quercus suber L. - Int. J. Plant Sci. 157: 674-684, 1996.

Sahgal, P., Martinez, G.V., Roberts, C., Tallman, G.: Regeneration of plants from cultured guard cell protoplasts of Nicotiana glauca (Graham). - Plant Sci. 97: 199-208, 1994.

Su, Y.J., Chen, J.T., Chang, W.C.: Efficient and repetitive production of leaf-derived somatic embryos of Oncidium. Biol. Plant. 50: 107-110, 2006.

Taylor, J.E., Abram, B., Boorse, G., Tallman, T.: Approaches to evaluating the extent to which guard cell protoplasts of Nicotiana glauca (tree tobacco) retain their characteristics when cultured under conditions that affect their survival, growth and differentiation. - J. exp. Bot. 49: 377-386, 1998.

Uzelac, B., Ninković, S., Smigocki, A., Budimir, S.: Origin and development of secondary somatic embryos in transformed embryogenic cultures of Medicago sativa. - Biol. Plant. 51: 1-6, 2007.

Von Arnold, S., Sabala, I., Bozhkov, I., Dyachok, J., Filonoval, L.: Developmental pathways of somatic embryogenesis. Plant Cell Tissue Organ Cult. 69: 233-249, 2005.

Williams, E.G., Maheswaran, G.: Somatic embryogenesis: factors influencing coordinated behaviour of cells as an embryogenic group. - Ann. Bot. 57: 443-462, 1986.

Wiśniewska, E., Majewska-Sawka, A.: Arabinogalactanproteins stimulate the organogenesis of guard cell protoplasts-derived callus in sugar beet. - Plant Cell Rep. 26: 1457-1467, 2007. 